\title{
PERAN TATA KELOLA PERUSAHAAN DALAM HUBUNGAN TAX AVOIDANCE DENGAN COST OF EQUITY
}

\section{Masripah, Shinta Widyastuti dan Amelia Sandra}

Universitas Pembangunan Nasional (UPN) Veteran Jakarta, Indonesia dan

Institut Bisnis dan Informatika Kwik Kian Gie

Email: masripah@upnvj.ac.id, shinta.widyastuti@upnvj.ac.id dan

amelia.sandra@kwikkiangie.ac.id

\begin{abstract}
This study aims to analyze the relationship between tax avoidance and cost of equity, and to see the role of board of commissioners' effectiveness, audit committee's effectiveness, and external audit quality on the relationship between tax avoidance and cost of equity. This study uses secondary data from annual financial reports and ICMD. Data analysis was performed using multiple regression with OLS. Data processing will be carried out using multiple regression methods. The number of samples consisted of 54 manufacturing companies from 2014 to 2018. The results provide empirical evidence that when companies do tax avoidance it will have an impact on low cost of equity. The role of board of commissioners' effectiveness, audit committee effectiveness, and external audit quality does not provide evidence that there is a significant effect on the relationship between tax avoidance and cost of equity.
\end{abstract}

Keywords: board of commissioners' effectiveness; audit committee's effectiveness; external audit quality; tax avoidance; cost of equity
Abstrak
Penelitian ini bertujuan untuk menganalisis hubungan antara tax avoidance dengan cost of equity, serta melihat peran efektivitas dewan komisaris, efektivitas komite audit, dan kualitas audit eksternal terhadap hubungan antara tax avoidance pada cost of equity. Penelitian ini menggunakan data sekunder laporan keuangan tahunan dan ICMD. Analisis data dilakukan dengan menggunakan regresi berganda dengan OLS. Pengolahan data dilakukan dengan metode regresi berganda. Jumlah sampel yang diambil 54 perusahaan mnufaktur dari tahun 2014 hingga 2018. Hasil penelitian memberikan bukti empiris bahwa saat perusahaan melakukan tax avoidance akan berdampak pada cost of equity yang rendah. Peran efektivitas dewan komisaris, efektivitas komite audit, dan kualitas audit eksternal tidak memberikan bukti bahwa terdapat pengaruh yang signifikan dalam hubungan antara tax avoidance dengan cost of equity.

Kata Kunci: efektivitas dewan komisaris, efektivitas komite audit, kualitas audit eksternal, tax avoidance, cost of equity

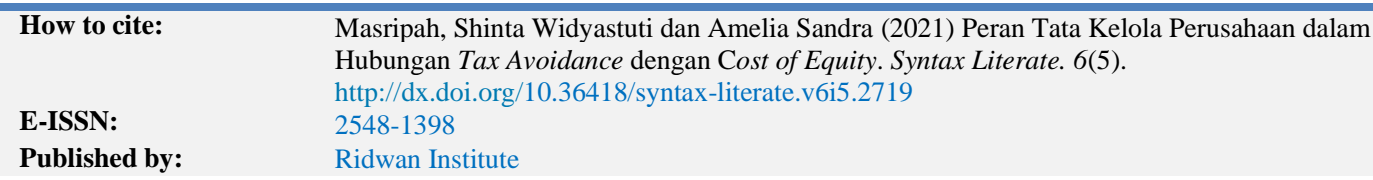




\section{Pendahuluan}

Pada umumnya seorang investor adalah risk averse (sikap yang tidak menyukai risiko). Oleh karena itu, mereka lebih memilih melakukan diversifikasi dalam portofolio investasinya guna mengurangi sebagian risiko yang harus ditanggungnya (Raymond Dantes, 2019). Namun, (Lambert, Leuz, \& Verrecchia, 2007) memberikan bukti bahwa meskipun kemampuan investor untuk diversifikasi risiko, tapi informasi kualitas akuntansi dan pengungkapan kualitas perusahaan yang lebih tinggi menyebabkan future cash flows yang diharapkan pada perusahaan lebih tinggi dan mengurangi cost of equity perusahaan. Jika investor menganggap tax avoidance sebagai aktivitas pengambilan risiko yang memiliki net present value positif, hal ini dapat meningkatkan future cash flows yang diharapkan dan mengurangi cost of equity.

Cost of equity merupakan tingkat pengembalian yang diinginkan oleh investor untuk mau menanamkan uangnya di perusahaan atau disebut juga sabagai tingkat imbal hasil saham yang dipersyaratkan (Utami, 2005). Penelitian (Goh, Lee, Lim, \& Shevlin, 2013) menyatakan bahwa tax avoidance dapat dikaitkan dengan cost of equity yang lebih rendah karena adanya penghematan kas dari pajak yang dapat didistribusikan untuk penggunaan yang lebih produktif, sehingga meningkatkan operasi dan keputusan investasi perusahaan. Bagi investor yang risk-neutral akan lebih memilih manajer yang risk-averse untuk terlibat dalam kegiatan perencanaan pajak berisiko yang memiliki net present value positif. Oleh karena itu investor mengharapkan future cash flows yang lebih tinggi untuk perusahaan yang melakukan tax avoidance dan cost of equity yang lebih rendah.

Menurut (Goetz, 1978) tax avoidance dapat didefinisikan sebagai pengurangan hukum pajak melalui penggunaan ketentuan preferensial undang-undang pajak. Penelitian (Dhaliwal, Krull, \& Li, 2007) menunjukkan bukti bahwa Undang-Undang Pajak yang menurunkan tarif pajak akan memengaruhi penurunan cost of equity. Tax avoidance tidak seperti tindakan pajak agresif yang kemungkinan perusahaan mendapat sanksi/penalti dari fiskus pajak (Sari \& Martani, 2010), karena tax avoidance merupakan tindakan legal, dapat dibenarkan karena tidak melanggar undang-undang, dalam hal ini sama sekali tidak ada suatu pelanggaran hukum yang dilakukan (Devano \& Rahayu, 2006). Tujuan penghindaran pajak adalah menekan atau meminimalisasi jumlah pajak yang harus dibayar.

Penelitian (Rego \& Wilson, 2012) menegaskan bahwa strategi pajak agresif mengakibatkan peningkatan agresivitas pajak yang menyebabkan peningkatan risiko pajak. Meningkatkan ketidakpastian mengenai masa depan arus kas setelah pajak perusahaan, maka investor membutuhkan tingkat pengembalian yang lebih tinggi untuk posisi pajak berisiko. Namun, bila manajer secara insentif terlibat dalam tax avoidance yang diharapkan dapat menghasilkan keuntungan bersih untuk perusahaan dan pemegang saham (Rego \& Wilson, 2012), maka nilai perusahaan akan naik dan cost of equity lebih rendah.

Penelitian (Wang, 2010) menunjukkan bahwa tax avoidance meningkatkan nilai perusahaan, terutama bagi perusahaan yang paling transparan. Oleh karena itu, agar 
perusahaan dapat meningkatkan kualitas akuntansi dengan tetap memperhatikan tindakan tax avoidance, maka diperlukan suatu mekanisme pengawasan atas tindakan manajemen tersebut. Mekanisme pengawasan tersebut dikenal dengan istilah tata kelola perusahaan. Penelitian yang dilakukan oleh (Chen, Chen, \& Wei, 2009) serta (Byun, Kwak, \& Hwang, 2008) menunjukkan bahwa perusahaan dengan tata kelola yang efektif memiliki cost of equity yang lebih rendah.

Penelitian (Friese, Link, \& Mayer, 2008) menyatakan bahwa perencanaan pajak yang terjadi dalam suatu perusahaan tergantung pada dinamika tata kelola di perusahaan tersebut. Sedangkan pada penelitian (Wahab \& Holland, 2012) dijelaskan bahwa terdapat hubungan yang kuat pada tindakan tata kelola perusahaan yang bisa diharapkan untuk memoderasi implikasi potensi pajak yang berhubungan dengan asimetri informasi antara pemegang saham dengan manajer. Hal ini didukung oleh penelitian (Rebecca \& Siregar, 2012) yang menyatakan bahwa penerapan tata kelola perusahaan berarti dianggap mampu meningkatkan pengawasan terhadap manajemen untuk mendorong pengambilan keputusan yang efektif, mencegah tindakan oportunistik yang tidak sesuai dengan kepentingan perusahan, dan mengurangi asimetri informasi antara pihak manajemen, shareholder, dan kreditur.

Menurut (Krismatono, Suprayitno, Yasni, Indaryanto, \& Susandy, 2006) mendefinisikan tata kelola perusahaan yang baik sebagai struktur, sistem, dan proses yang digunakan oleh organ perusahaan guna memberikan nilai tambah perusahaan yang berkesinambungan dalam jangka panjang. Aspek penilaian yang cukup menentukan bagi keberhasilan implementasi tata kelola perusahaan yang baik diantaranya ialah komitmen penuh dari peran dewan komisaris, keberadaan komite audit yang efektif, dan keterbukaan laporan keuangan perusahaan kepada publik (Effendi, 2009).

Berdasarkan uraian di atas, penelitian ini dilakukan untuk mengetahui pengaruh "Peran tata kelola perusahaan dalam hubungan tax avoidance dengan cost of equity". Penelitian ini menguji apakah investor di Bursa Efek Indonesia sudah memperhitungkan besaran tindakan penghindaran pajak dalam menentukan tingkat imbal hasil saham yang dipersyaratkan. Jika investor telah memperhitungkan besaran penghindaran pajak dalam menentukan tingkat imbal hasil saham dengan memperhatikan peran tata kelola perusahaan, maka investor dapat mengantisipasi adanya praktik agresivitas pajak yang dilakukan oleh emiten.

(Suandy, 2008) mengartikan pajak sebagai pemindahan sumber daya dari sektor privat (perusahaan) ke sektor publik. Pemindahan sumber daya tersebut akan memengaruhi daya beli atau kemampuan belanja dari perusahaan. Dengan demikian, pembayaran akan kewajiban perpajakan harus dikelola dengan baik agar tidak terjadi gangguan yang serius terhadap jalannya perusahaan. Pengelolan dengan baik tersebut diperlukan dalam perencanaan perpajakan yang efektif saat investasi yang baru lebih padat modal karena akan berpengaruh terhadap investasi yang akan dilakukan.

Perencanaan pajak dengan maksud penghematan pembayaran pajak ini dikategorikan menjadi tax evasion atau tax avoidance (Hutagaol, 2007). Tindakan penghematan pajak yang bertentangan dengan ketentuan perpajakan disebut sebagai tax 
evasion. Bila tidak bertentangan dengan ketentuan perpajakan yang berlaku, maka tindakan penghematan pajak tersebut masuk dalam kategori tax avoidance. Pengklasifikasian tax evasion dan tax avoidance tidak sesederhana itu dalam praktik sesungguhnya, karena perbedaan antara keduanya sangat tipis. Perusahaan yang semula bermaksud melakukan tax avoidance, tetapi bisa saja secara tidak sadar telah melakukan tax evasion.

Dampak yang dihasilkan dari tindakan tax avoidance dan tax evasion berbeda. Pada perusahaan yang melakukan tax evasion dapat memberikan risiko yang besar pada perusahaan dan menurunkan nilai perusahaan. Sedangkan perusahaan yang melakukan penghematan pajak (tax avoidance) tanpa melanggar undang-undang yang berlaku dapat meningkatkan keputusan perusahaan seperti produksi dan investasi, sehingga meningkatkan arus kas perusahaan yang diharapkan dan mengurangi biaya ekuitas (Goh et al., 2013). Pada penelitian ini ingin menguji hubungan antara tax avoidance yang dilakukan perusahaan dengan biaya ekuitas.

Menurut (Rebecca \& Siregar, 2012), penerapan tata kelola perusahaan dianggap mampu meningkatkan pengawasan terhadap manajemen untuk mendorong pengambilan keputusan yang efektif, mencegah tindakan oportunistik yang tidak sesuai dengan kepentingan perusahan, dan mengurangi asimetri informasi antara pihak manajemen, shareholder, dan kreditur. Perusahaan yang telah melakukan tata kelola yang baik, diharapkan dapat membatasi perusahaan dalam melakukan penghematan pajak (tax avoidance) tidak secara agresif (tax evasion).

Mekanisme tata kelola perusahaan mencerminkan peran aktif dewan komisaris dalam membawa aspirasi atau kepentingan pemegang saham minoritas, bekerjanya komite audit yang bisa dipertanggungjawabkan sehingga informasi laporan keuangan tidak diragukan kualitasnya, dan semakin meningkatnya transparansi pengungkapan pelaporan keuangan (Investasi, 2010). Pada penelitian ini melihat peran dari mekanisme tata kelola perusahaan yang diukur dengan efektivitas dewan komisaris, efektivitas komite audit, dan kualitas audit eksternal.

Dewan komisaris dalam melaksanakan tugasnya diharapkan dapat bersikap independen dan selalu memperhatikan kepentingan perusahaan, pemegang saham, dan para pemangku kepentingan lainnya di atas kepentingan pribadi atau golongan. Efektivitas dewan komisaris diukur dengan menganalisis laporan tahunan perusahaan (independensi, aktivitas, jumlah anggota, kompetensi) untuk menentukan apakah dewan komisaris telah menjalankan fungsinya secara efektif.

Komite audit yang melaksanakan tugasnya dalam bidang tata kelola perusahaan secara efektif dapat mengurangi adanya kecurangan yang dilakukan oleh karyawan ataupun manajemen perusahaan. Keahlian di bidang akuntansi dan keuangan yang dimiliki komite audit diharapkan dapat mengurangi adanya peluang tindakan penghindaran pajak dengan memastikan perusahaan telah dijalankan sesuai dengan undang-undang dan peraturan yang berlaku dan melaksanakan usahanya dengan beretika. Efektivitas komite audit diukur dengan menganalisis laporan tahunan 
perusahaan (aktivitas, jumlah anggota, kompetensi) untuk menentukan apakah komite audit telah menjalankan fungsinya secara efektif.

Kualitas audit eksternal dapat menjelaskan kondisi perusahaan yang tercermin dari laporan keuangan perusahaan. (Wiryadi \& Sebrina, 2013) mendefinisikan kualitas audit sabagai kemungkinan seorang auditor akan menemukan dan melaporkan pelanggaran yang ada dalam sistem akuntansi kliennya. Dengan demikian, salah satu alternatif untuk mengukur kualitas audit bisa dengan membandingkan kelompok auditor satu dengan yang lainnya. Penelitian ini akan menggunakan kantor akuntan publik Big 4 untuk menentukan kualitas audit yang dihubungkan dengan penghematan pajak perusahaan seperti yang dilakukan dalam penelitian (Richardson, Taylor, \& Lanis, 2013).

Tingkat imbal hasil saham yang dipersyaratkan adalah tingkat pengembalian yang diinginkan oleh investor untuk mau menanamkan uangnya di perusahaan, dan dikenal dengan sebutan biaya modal ekuitas (Utami, 2005). Sedangkan menurut (Investasi, 2010) cost of equity adalah biaya yang dikeluarkan untuk membiayai sumber pembelanjaan atau diidentifikasi sebagai tingkat return minimum yang disyaratkan oleh penggunaan modal ekuitas atas investasi. Penelitian ini ingin melihat bagaimana tax avoidance yang dilakukan perusahaan memengaruhi cost of equity dan mekanisme tata kelola perusahaan yang mengurangi estimaasi berperan pada hubungan keduanya.

Penelitian Wang (2010) menyatakan bahwa tax avoidance yang mengurangi transfer dari pemegang saham kepada pemerintah secara tradisional dipandang sebagai meningkatkan nilai kepada pemegang saham. Peningkatan nilai kepada pemegang saham ini akan berdampak pada cost of equity yang rendah. Sesuai dengan penelitian (Goh et al., 2013) yang menyatakan bahwa tax avoidance dapat dikaitkan dengan cost of equity yang lebih rendah. Oleh karena itu, hipotesis pertama pada penelitian ini adalah:

H1: terdapat hubungan yang signifikan negatif antara tax avoidance dengan cost of equity.

(Byun et al., 2008) memaparkan bahwa perusahaan yang meningkatkan tata kelola perusahaan berarti meningkatkan kualitas laporan keuangan perusahaan, dan demikian cost of equity perusahaan menjadi lebih rendah. Sesuai dengan penelitian (Chen et al., 2009) membuktikan bahwa tata kelola perusahaan yang efektif dapat meningkatkan nilai perusahaan melalui penurunan masalah keagenan dan karenanya cost of equity lebih rendah. (Rebecca \& Siregar, 2012) juga membuktikan bahwa Corporate Governance Index memiliki pengaruh negatif signifikan terhadap cost of equity. Hal ini menunjukkan bahwa kualitas dari praktek tata kelola perusahaan dapat mengurangi cost of equity. Penelitian ini akan menguji peran mekanisme tata kelola perusahaan dengan melihat peran efektivitas dewan komisaris, efektivitas komite audit, dan kualitas audit eksternal yang mencerminkan transparansi pengungkapan pelaporan keuangan.

Penerapan tata kelola perusahaan melalui efektivitas peran dewan komisaris dan komite audit akan memengaruhi proses pelaporan keuangan perusahaan, serta fungsi 
pengawasannya dapat mencegah tindakan manajemen yang bersifat opportunistic dan tidak selaras dengan kepentingan pemegang saham (Hermawan, 2009). Peran aktif dewan komisaris akan mengurangi risiko bagi investor maupun calon investor yang berminat menanamkan dananya pada suatu perusahaan (Investasi, 2010). Menurut (Ashbaugh, Collins, \& LaFond, 2004) menunjukkan bahwa komposisi dewan independen berpengaruh negatif terhadap cost of equity capital, artinya semakin banyak jumlah dewan yang berasal dari luar maka fungsi pengawasan yang mereka lakukan akan semakin efektif sehingga dapat meminimalkan risiko agensi dan cost of equity capital menjadi rendah. Dengan demikian, hipotesis kedua pada penelitian ini adalah:

H2: efektivitas dewan komisaris memperkuat hubungan antara tax avoidance pada cost of equity.

Komite audit merupakan pihak yang melakukan pengawasan dan pengendalian untuk menjamin transparansi, keterbukaan laporan keuangan, keadilan untuk semua stakeholder, dan pengungkapan semua informasi yang telah dilakukan oleh manajemen meski ada konflik kepentingan (Pamudji \& Trihartati, 2010). Hasil temuan (Hermawan, 2009) menunjukkan bahwa karakteristik aktivitas komite audit memiliki pengaruh positif dan signifikan terhadap kualitas laba, dimana komite audit yang menjalankan fungsinya dengan aktif akan meningkatkan kredibilitas pelaporan keuangan perusahaan di mata investor. Penelitian (Ashbaugh et al., 2004) menunjukkan bahwa komite audit independen berpengaruh negatif terhadap cost of equity capital yang artinya komite audit lebih independen akan mengurangi risiko informasi dan juga asimetri informasi sehingga cost of equity capital menjadi rendah. Dengan demikian, hipotesis keempata penelitian ini adalah:

H3: efektivitas komite audit memperkuat hubungan antara tax avoidance pada cost of equity.

Laporan keuangan perusahaan yang handal dan dipercaya akan meningkatkan permintaan sekuritas dan harga pasar saham perusahaan, pada akhirnya akan menurunkan cost of equity (Investasi, 2010). Penelitian (Khurana \& Raman, 2004) juga menemukan bahwa kualitas audit yang diukur menggunakan KAP big four mampu memberikan assurance yang lebih tinggi atas keandalan laporan keuangan sehingga perusahaan yang diaudit oleh KAP big four memiliki cost of equity lebih rendah dibandingkan dengan perusahaan yang diaudit oleh non-big four. Dengan demikian, hipotesis keempat pada penelitian ini adalah:

H4: kualitas audit eksternal memperkuat hubungan antara tax avoidance pada cost of equity.

\section{Metode Penelitian}

Rerangka pemikiran yang melandasi pengembangan hipotesis pada penelitian ini yaitu: 


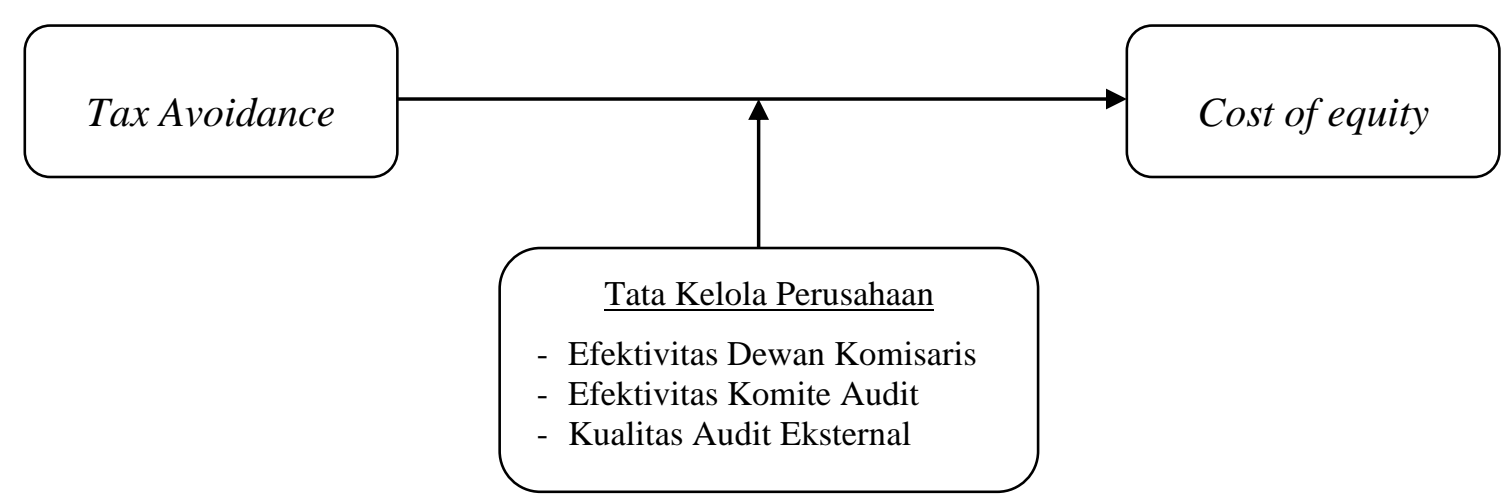

Jenis riset meliputi modelling dengan membuat model berdasarkan kerangka pemikiran dan hipotesis penelitian.

Penelitian ini menggunakan satu model persamaan untuk menguji empat hipotesis penelitian. Model persamaan dibuat untuk menguji peran efektivitas dewan komisaris, efektivitas komite audit, dan kualitas audit eksternal dalam penghindaran pajak dengan cost of equity, sebagaimana dinyatakan dalam hipotesis 1, 2, 3, dan 4 . Berikut ini model persamaan tersebut yaitu:

\section{Model 1:}

$\mathrm{COE}_{i \mathrm{t}}=\alpha+\beta 1 \mathrm{TaxAvd}_{\mathrm{it}}+\beta 2 \mathrm{ROA}_{\mathrm{it}}+\beta 3 \mathrm{LEV}_{\mathrm{it}}+\beta 4 \mathrm{PPE}_{\mathrm{it}}+\beta 5 \mathrm{MB}_{\mathrm{it}}+\varepsilon_{\mathrm{it}}$

Model 2:
$\mathrm{COE}_{\mathrm{it}}=\alpha+\beta 1 \mathrm{TaxAvd}_{\mathrm{it}}+\beta 2 \mathrm{EDK}_{\mathrm{it}}+\beta 3 \mathrm{EKA}_{\mathrm{it}}+\beta 4 \mathrm{KAE}_{\mathrm{it}}+\beta 5 \mathrm{TaxAvd}_{\mathrm{it}}{ }^{*} \mathrm{EDK}_{\mathrm{it}}+$ $\beta 6 \mathrm{TaxAvd}_{i t}{ }^{*} \mathrm{EKA}_{\mathrm{it}}+\beta 7 \mathrm{TaxAvd}_{\mathrm{it}}{ }^{*} \mathrm{KAE}_{\mathrm{it}}+\beta 8 \mathrm{ROA}_{\mathrm{it}}+\beta 9 \mathrm{LEV}_{\mathrm{it}}+\beta 10 \mathrm{PPE}_{\mathrm{it}}+$ $\beta 11 \mathrm{MB}_{\text {it }}+\varepsilon_{\text {it... }}$

$\mathrm{COE}_{\text {it }}$ ialah cost of equty; TaxAvd $\mathrm{d}_{\mathrm{it}}$ ialah pnghindaran pajak yang diukur dengan BTD; EDK ialah efektifitas dewan komisaris; EKA merupakan efektifitas komite audit; KAE merupakan kualitas audit eksternal; TaxAvd*EDK merupakan variabel interaksi TaxAvd dan EDK; TaxAvd*EKA merupakan variabel interaksi TaxAvd dan EKA; TaxAvd*KAE ialah variabel interaksi TaxAvd dan KAE; ROAit ialah return on asset untuk perusahaan i, tahun $t$; LEVit ialah Leverage untuk perusahaan i, tahun $t$; PPEit ialah property, plant, dan equipment perusahaan i pada tahun t; MBit ialah market-tobook ratio untuk perusahaan i, pada awal tahun t.

Sampel penelitian adalah semua perusahaan manufaktur yang terdaftar di Bursa Efek Indonesia pada tahun 2014 sampai 2018. Jenis data yang dipakai dalam penelitian ini adalah data sekunder. Berikut ini penjelasan sumber untuk memperoleh data sekunder yang digunakan dalam penelitian ini.

a) Data indeks penilaian efektivitas dewan komisaris dan efektivitas komite audit diperoleh dengan menghitung skor (independensi, ukuran, aktivitas, keahlian dan kompetensi) seperti yang dilakukan oleh (Hermawan, 2009) berdasarkan informasi yang tertera dalam laporan tahunan perusahaan manufaktur yang didapat dari situs resmi BEI ataupun di situs resmi perusahaan tersebut.

b) Data-data variabel dependen, variabel kontrol, dan kualitas eksternal audit diperoleh dari laporan keuangan dan Indonesia Capital Market Directory (ICMD). 
Prosedur yang digunakan dalam menganalisis data adalah menggunakan model regresi berganda dengan OLS. Program yang digunakan untuk menguji model penelitian yaitu Stata. Uji F juga dilakukan untuk menguji uji signifikansi koefisiensi regresi secara bersama-sama. Pengujian hipotesis dilakukan dengan melakukan uji-t terhadap koefisien regresi.

\section{Hasil dan Pembahasan}

Penelitian ini mengambil sampel perusahaan manufaktur yang terdaftar di Bursa Efek Indonesia dengan laporan keuangan dari tahun 2014 sampai dengan tahun 2018. Total sampel yang diambil dalam penelitian ini terdiri dari 54 perusahaan yang terdiri dari 270 firm year membahas peran tata kelola perusahaan dalam hubungan tax avoidance dengan cost of equity. Obyek populasi pada penelitian ini adalah perusahaan manufaktur yang terdaftar di Bursa Efek Indonesia. Sampel penelitian ini yaitu 54 perusahaan manufaktur yang menerbitkan laporan keuangan selama tahun 2014 sampai tahun 2018 secara berturutturut.

\section{A. Tax Avoidance dan Cost of Equity}

Pada hasil regresi membuktikan bahwa nilai probabilitas untuk variabel tax avoidance sebesar 0,048 lebih kecil daripada 0,05. Artinya, hal ini menunjukkan bahwa terdapat hubungan antara tax avoidance dengan cost of equity. Dimana pada hasil regresi, nilai koefisien variabel tax avoidance sebesar -0,1540229. Dengan demikian dapat disimpulkan bahwa adanya hubungan negatif antara tax avoidance dengan cost of equity. Hal ini sesuai dengan penelitian (Goh et al., 2013) yang menyatakan bahwa tax avoidance dapat dikaitkan dengan cost of equity yang lebih rendah. Sesuai juga dengan penelitian (Wang, 2010) yang menyatakan bahwa tax avoidance yang mengurangi transfer dari pemegang saham kepada pemerintah secara tradisional dipandang sebagai meningkatkan nilai kepada pemegang saham. Peningkatan nilai kepada pemegang saham ini akan berdampak pada cost of equity yang rendah.

B. Peran Efektifitas Dewan Komisaris dalam Hubungan Tax Avoidance dengan Cost of Equity

Hipotesis $2\left(\mathrm{H}_{2}\right)$ menyatakan bahwa efektivitas dewan komisaris memperkuat hubungan antara tax avoidance pada cost of equity. Hasil penelitian menunjukkan arah positif tetapi tidak signifikan. Dengan demikian, hipotesis kedua penelitian ini tidak dapat diterima (tidak terbukti). Hasil penelitian ini menjelaskan bahwa efektifitas dewan komisaris tidak berperan dalam hubungan tax avoidance dengan cost of equity. Kemungkinan tidak adanya pengaruh efektifitas dewan komisaris pada hubungan dalam hal ini dikarenakan kecenderungan dalam pelaksanaan tanggung jawab antara dewan komisaris dan dewan direksi. Dimana dewan komisaris yang bertugas sebagai pengawas dan memberi nasehat lebih cenderung fokus pada kebijakan pengurusan perusahaan yang dilaksanakan oleh dewan direksi. Dewan komisaris tidak memperhatikan tindakan penghindaran pajak yang dilakukan dewan direksi, karena tindakan tersebut tidak melanggar peraturan yang ada di dalam perundang-undangan perpajakan. Sedangkan direksi cenderung fokus pada optimalisasi laba perusahaan 
untuk meningkatkan nilai kepada pemegang saham. Tindakan penghindaran pajak (tax avoidance) merupakan salah satu cara yang dapat dilakukan oleh dewan direksi.

C. Peran Efektifitas Komite Audit dalam Hubungan Tax Avoidance dengan Cost of Equity

Hipotesis $3\left(\mathrm{H}_{3}\right)$ menyatakan bahwa efektivitas komite audit memperkuat hubungan antara tax avoidance pada cost of equity. Hasil penelitian menunjukkan arah negatif dan tidak signifikan. Dengan demikian, hipotesis kedua penelitian ini tidak dapat diterima (tidak terbukti). Hasil penelitian ini menjelaskan bahwa efektifitas komite audit tidak memengaruhi dalam hubungan tax avoidance dengan cost of equity. Menurut peraturan OJK nomor 55/POJK.04/2015, komite audit dibentuk oleh Dewan Komisaris dan memiliki tanggung jawab kepada Dewan Komisaris dalam melaksanakan fungsi dan tugas dewan komisaris. Salah satu tugas komite audit yang akan dipertanggungjawabkan ialah menelaah ketaatan perusahaan terhadap peraturan perundang-undangan. Penjelasan yang bisa dijadikan alasan hasil penelitian tidak berpengaruh, yaitu komite audit tidak terlalu memperhatikan tindakan penghindaran pajak (tax avoidance) yang dilakukan oleh dewan direksi.

D. Peran Kualitas Audit Eksternal dalam Hubungan Tax Avoidance dengan Cost of Equity

Hipotesis $4\left(\mathrm{H}_{4}\right)$ menyatakan bahwa kualitas audit eksternal memperkuat hubungan antara tax avoidance pada cost of equity. Hasil penelitian menunjukkan arah positif tetapi tidak signifikan. Dengan demikian, hipotesis keempat penelitian ini tidak dapat diterima (tidak terbukti). Hasil penelitian ini menjelaskan bahwa kualitas audit eksternal tidak memiliki peran dalam hubungan tax avoidance dengan cost of equity. Kualitas audit eksternal yang baik diukur dengan KAP big 4. Namun hasil penelitian menyatakan kualitas audit eksternal tidak berpengaruh. Artinya, KAP big 4 dan KAP non big 4 sudah memeriksa laporan keuangan serta ketaatan pajak sesuai prosedur audit. Tetapi tidak mempertimbangkan tindakan penghindaran pajak (tax avoidance) yang mungkin dilakukan dewan direksi agar cost of equity menjadi rendah.

\section{Kesimpulan}

Hasil penelitian ini memberikan bukti bahwa terdapat hubungan yang signifikan negatif antara tax avoidance dengan cost of equity. Artinya, saat perusahaan melakukan penghindaran pajak akan meningkatkan nilai kepada pemegang saham yang berdampak pada cost of equity yang rendah. Namun, hasil penelitian ini tidak memberikan bukti empiris terdapatnya peran efektifitas dewan komisaris, efektifitas komite audit, dan kualitas audit eksternal dalam hubungan tax avoidance dengan cost of equity.

Penelitian ini memberikan kontribusi ilmiah dan tambahan bukti empiris terkait pengaruh tax avoidance terhadap cost of equity pada perusahaan manufaktur yang terdaftar di BEI. Saran teoritis untuk para peneliti selanjutnya yaitu menggunakan proxy yang berbeda untuk pengukuran tax avoidance, seperti ETR, CETR, ataupun Cash ETR, dan melakukan uji beda. Sehingga memungkinkan penelitian untuk memberikan kesimpulan yang lebih valid. 


\section{BIBLIOGRAFI}

Ashbaugh, Hollis, Collins, Daniel W., \& LaFond, Ryan. (2004). Corporate governance and the cost of equity capital. Emory, University of Iowa. Retrieved on January, 26, 2006. Google Scholar

Byun, Hae Young, Kwak, Su Keun, \& Hwang, Lee Seok. (2008). The implied cost of equity capital and corporate governance practices. 한국증권학회지, 37(1), 139184. Google Scholar

Chen, Kevin C. W., Chen, Zhihong, \& Wei, K. C. John. (2009). Legal protection of investors, corporate governance, and the cost of equity capital. Journal of Corporate Finance, 15(3), 273-289. Google Scholar

Devano, Sony, \& Rahayu, Siti Kurnia. (2006). Perpajakan: Konsep, teori, dan isu. Google Scholar

Dhaliwal, Dan, Krull, Linda, \& Li, Oliver Zhen. (2007). Did the 2003 Tax Act reduce the cost of equity capital? Journal of Accounting and Economics, 43(1), 121-150. Google Scholar

Effendi, Muh Arief. (2009). The power of good corporate governance: teori dan implementasi. Jakarta: Salemba Empat. Google Scholar

Friese, Arne, Link, Simon, \& Mayer, Stefan. (2008). Taxation and corporate governance-The state of the art. In Tax and corporate governance (pp. 357-425). Springer. Google Scholar

Goetz, Michael L. (1978). Tax avoidance, horizontal equity, and tax reform: a proposed synthesis. Southern Economic Journal, 798-812. Google Scholar

Goh, Beng Wee, Lee, Jimmy, Lim, Chee Yeow, \& Shevlin, Terry. (2013). The effect of corporate tax avoidance on the cost of equity. Google Scholar

Hermawan, Ancella A. (2009). Pengaruh efektifitas dewan komisaris dan komite audit, kepemilikan oleh keluarga, dan peran monitoring bank terhadap kandungan informasi laba. Disertasi S3 Program Ilmu Akuntansi. Universitas Indonesia. Google Scholar

Hutagaol, John. (2007). Perpajakan isu-isu kontemporer. Yogyakarta: Graha Ilmu. Google Scholar

Investasi, Jurnal. (2010). Mekanisme Tata Kelola Korporat: Mampukah Menurunkan Cost Of Equity Capital? Jurnal Investasi, 6(1). Google Scholar

Khurana, Inder K., \& Raman, K. K. (2004). Litigation risk and the financial reporting credibility of Big 4 versus non-Big 4 audits: Evidence from Anglo-American countries. The Accounting Review, 79(2), 473-495. Google Scholar 
Krismatono, Dadi, Suprayitno, G., Yasni, Sedarnawati, Indaryanto, Khomsiyah G., \& Susandy, May. (2006). Komitmen menegakkan Good Coporate Governance: praktik terbaik penerapan Good Corporate Governance perusahaan publik di Indonesia. Language, 32(277p), 24cm. Google Scholar

Lambert, Richard, Leuz, Christian, \& Verrecchia, Robert E. (2007). Accounting information, disclosure, and the cost of capital. Journal of Accounting Research, 45(2), 385-420. Google Scholar

Pamudji, Sugeng, \& Trihartati, Aprillya. (2010). Pengaruh Independensi dan Efektivitas Komite Audit Terhadap Manajemen Laba. Jurnal Dinamika Akuntansi, 2(1). Google Scholar

Raymond Dantes, Raymond Dantes. (2019). Wawasan Pasar Modal Syariah. Google Scholar

Rebecca, Yulisa, \& Siregar, Sylvia Veronica. (2012). Pengaruh corporate governance index, kepemilikan keluarga, dan kepemilikan institusional terhadap biaya ekuitas dan biaya utang: studi empiris pada perusahaan manufaktur yang terdaftar di BEI. Simposium Nasional Akuntansi XV, 1-28. Google Scholar

Rego, Sonja Olhoft, \& Wilson, Ryan. (2012). Equity risk incentives and corporate tax aggressiveness. Journal of Accounting Research, 50(3), 775-810. Google Scholar

Richardson, Grant, Taylor, Grantley, \& Lanis, Roman. (2013). The impact of board of director oversight characteristics on corporate tax aggressiveness: An empirical analysis. Journal of Accounting and Public Policy, 32(3), 68-88. Google Scholar

Sari, Dewi Kartika, \& Martani, Dwi. (2010). Karakteristik Kepemilikan Perusahaan. Corporate Governance, 1-34. Google Scholar

Suandy, E. (2008). Perencanaan Pajak (Edisi 4, ed.). Jakarta: Salemba Empat. Google Scholar

Utami, W. (2005). Pengaruh Manajemen Laba Terhadap Biaya Modal Ekuitas (Studi pada Perusahaan Publik Sektor Manufaktur). Dalam SNA VIII, 15-16 September, Solo. Google Scholar

Wahab, Nor Shaipah Abdul, \& Holland, Kevin. (2012). Tax planning, corporate governance and equity value. The British Accounting Review, 44(2), 111-124. Google Scholar

Wang, X. (2010). Tax avoidance, Corporate Transparency, and Firm Value. Dalam Dessertation, Desember, The University of Texas at Austin. Google Scholar

Wiryadi, Arri, \& Sebrina, Nurzi. (2013). Pengaruh asimetri informasi, kualitas audit, dan struktur kepemilikan terhadap manajemen laba. Wahana Riset Akuntansi, 1(2), 155-180. Google Scholar 
Peran Tata Kelola Perusahaan dalam Hubungan Tax Avoidance dengan Cost of Equity

\section{Copyright holder:}

Masripah, Shinta Widyastuti dan Amelia Sandra (2021)

First publication right:

Journal Syntax Literate

This article is licensed under:

(c) $\odot \bigodot_{\mathrm{BY}}$ 